\title{
CLAY IMPROVED DISPERSION OF CARBON NANOTUBES IN DIFFERENT SOLVENTS
}

\author{
Aleksandra Ivanoska-Dacikj ${ }^{{ }^{*}}$, Gordana Bogoeva-Gaceva ${ }^{1,2}$, Aleksandra Buzarovska ${ }^{2}$ \\ ${ }^{1}$ Research Center for Environment and Materials, Macedonian Academy of Sciences and Arts, \\ Skopje, Republic of Macedonia \\ ${ }^{2}$ Faculty of Technology and Metallurgy, Ss. Cyril and Methodius University, \\ Skopje, Republic of Macedonia \\ *Corresponding author, e-mail: aivanoska@manu.edu.mk
}

\begin{abstract}
Hybrid nanofillers composed of different ratios of carbon nanotubes (CNTs) and sodium montmorillonite (MMT) were prepared by physically pulverizing both materials in powder form. Their dispersion behavior was investigated in different solvents (water, toluene and carbon tetrachloride). UV-vis spectroscopy showed that the absorbance at $550 \mathrm{~nm}$ for the CNTs becomes more intense with the increasing amount of added MMT, when water is used as a solvent, implying their improved dispersion. This is not so evident for toluene and carbon tetrachloride. TGA analyses showed that the thermal stability of the hybrid nanofillers increases with the increase of the MMT content. Raman spectroscopy confirmed the mutual interaction between CNTs and MMT, demonstrated by shift of D and G band with addition of MMT in the nanofiller.
\end{abstract}

Key words: hybrid nanofiller; carbon nanotubes; montmorillonite; dispersion

\section{INTRODUCTION}

Since their discovery in 1991 [1] great interest has been shown in carbon nanotubes (CNTs) both in the theoretical understanding and in practical applications. This interest has been driven by the unique structural and superior electrical, thermal and mechanical properties of these materials [2]. However, due to their lengthy geometric shape and strong Van der Waals force attraction, estimated at $500 \mathrm{eV} / \mu \mathrm{m}$ of tube length [3], CNTs tend to aggregate. Also, their chemical inertness leads to poor dispersion capability and weak interfacial interaction. These factors may consequently hinder the successful application of CNTs' unique properties. To overcome these problems different methods of functionalization are developed. Covalent functionalizations mainly tend to open the nanotubes by oxidative damage of their framework by strong acids [4], strong oxidants [5], ozone [6] or reactive plasma [7] and to subsequently generate oxygenated functional groups such as carboxyl, ketone, al- cohol and ester groups, that serve to bound many different types of chemical moieties onto the ends and defect sites of the nanotubes. However, these methods have their drawbacks. During the functionalization reaction a large number of defects are created on the CNTs sidewalls, and in some extreme cases, CNTs are fragmented into smaller pieces. This results in severe degradation of the mechanical properties of CNTs as well as in disruption of $\pi$ electron system in nanotubes which weakens their electrical and thermal conductivity. Another drawback is that concentrated acids or strong oxidants are often used for CNT functionalization which is inconvenient from environmental point of view. That is why noncovalent bonding modification is preferred. Suitable surfactants [8], polymers [9] and biomolecules [10] are commonly used as modifiers. Recently, it was demonstrated that pigment particles [11], carbon black [12] and CNTs [13] may be efficiently dispersed with the help of charged clay particles. Particularly, it was shown that introduction of charged nanoparticles (e.g. 
montmorillonite (MMT)) may significantly improve the dispersability of multiwalled CNTs in different media [13-15].

In the present work, we investigate the dispersion behavior of hybrid nanofillers, composed of different ratios of CNTs and MMT, in various solvents (water, toluene, carbon tetrachloride). The idea was, by a simple preparation of a physical mixture of the two nanomaterials with different geometric shapes, tubelike CNTs and plate-like MMT, to affect the CNTs' self aggregating forces. Adsorption and immobilization of CNTs on MMT particles should prevent them from collision and reaggregation $[14,15]$. The choice of the solvents corresponds to our final goal, improved CNTs dispersion in natural rubber (NR) and successful preparation of NR based nanocomposites [16]. Most common routes to obtain elastomeric nanocomposites are latex compounding (NR latex is water based), solution mixing (toluene is the most used organic solvent). Carbon tetrachloride was chosen because the value of its solubility parameter $\delta(\mathrm{H})=$ $8.6 \mathrm{cal}^{1 / 2} \mathrm{~cm}^{-3 / 2}$ is quite close to the value of the solubility parameter of NR, $\delta(\mathrm{H})=8.3 \mathrm{cal}^{1 / 2} \mathrm{~cm}^{-3 / 2}$. The state of dispersion was initially assessed with a bare eye and then further measured by analyzing the suspensions using UV-visible spectrometry. Raman spectroscopy was used to demonstrate the interaction between the nanofillers. The thermal stability of the hybrid nanofillers was evaluated by TGA analysis. The obtained results are expected to be a good contribution in identifying an easy, efficient, economical, ecological and industrially viable way of producing easily dispersible, super reinforcing hybrid nanofiller.

\section{EXPERIMENTAL SECTION}

Materials. Carbon nanotubes, NC7000, a multiwall carbon nanotubes produced by catalytic carbon vapor deposition (CCVD) process, were supplied by NANOCYL S. A. (Belgium). The CNTs are $90 \%$ pure containing $10 \%$ metal oxides and have average diameter of $9.5 \mathrm{~nm}$ and average length of $1.5 \mu \mathrm{m}$. Sodium montmorillonite (MMT) with commercial name CLOISITE $\mathrm{Na}^{+}$was supplied by Southern Clay Products Inc. (USA). It is a natural bentonite with typical dry particle size $<25 \mu \mathrm{m}$ and average intergallery distance $d_{001}=1.17 \mathrm{~nm}$.

Preparation of CNT/MMT hybrid nano-

filler. Hybrid nanofillers were prepared at different MMT-to-CNT weight ratios, or $\alpha$ values, of $1,2,4$, $6,8,10,12$ and 14 . The procedure of the preparation was as follows; $1 \mathrm{mg}$ of CNTs and adequate quantity of MMT (from $1 \mathrm{mg}$ to $14 \mathrm{mg}$ ) were ground in a mortar and pestle with homogeneous stirring for 5 minutes. The sides of the mortar were occasionally scraped down with the pestle to ensure a thorough mixing. The mixture was washed from the mortar and pestle with $20 \mathrm{~g}$ of the solvents (deionized water, toluene or carbon tetrachloride). The samples of the hybrid nanofillers used for TGA and Raman spectroscopy characterization were obtained from water solutions. The solutions were centrifuged for 5 minutes at $5000 \mathrm{rpm}$ and then dried $48 \mathrm{~h}$ at $35^{\circ} \mathrm{C}$.

Characterization. Ultraviolet-visible (UVvis) absorbance was measured by a HP $8452 \mathrm{~A} \mathrm{Di}-$ ode Array UV-vis spectrometer at $550 \mathrm{~nm}$. Thermogravimetric analysis (TGA) was performed on a Perkin-Elmer Pyris Diamond thermogravimetric analyzer (TG/DTA). The weight of the samples was in the range of 3.0-3.5 mg. The samples were heated at a heating rate of $10{ }^{\circ} \mathrm{C} / \mathrm{min}$ from 30 to $900{ }^{\circ} \mathrm{C}$ in air atmosphere using ceramic pans. The Raman spectra of CNTs and MMT/CNT hybrid nanofillers were obtained using the $633 \mathrm{~nm}$ YAG laser line from a micro-Raman spectrometer (Horiba JobinYvon LabRam Infinity) with a focal length of 50×.

\section{RESULTS AND DISCUSSION}

Similar to the stacking of individual graphene layers in graphite, the Van der Waals and $\pi-\pi$ stacking interactions are responsible for a strong attraction between individual CNTs. Accordingly, they tend to form bundles (of up to 100 individual nanotubes) and can be hardly dispersed in the absence of surfactants that shield the nanotube surface. However, when they were properly ground with plate-like MMT, the pulverized powders as a physical mixture became dispersible in water. This was first observed simply with bare eye, higher $\alpha$ value resulted in darker solution (Figure 1), which is an indication that more CNTs are exfoliated and dispersed in the water with the increasing amount of added MMT in the hybrid nanofiller.

On the other hand this was not observed for the suspensions in toluene (Figure 2) and carbon tetrachloride.

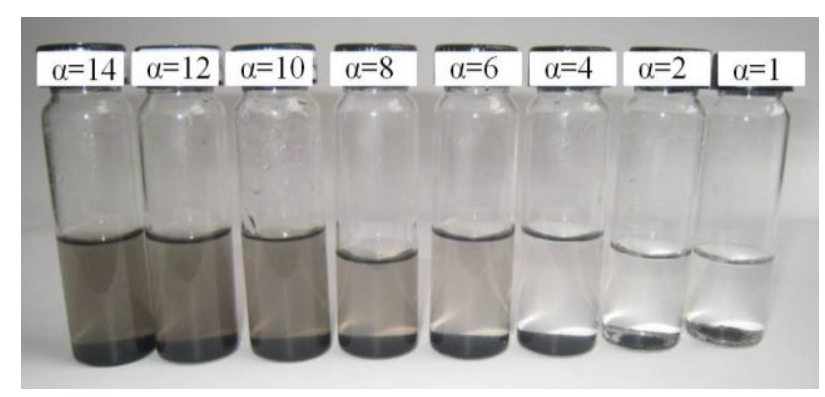

Figure 1. Evolution of the color of the aqueous solutions of hybrid nanofillers with different MMT-to-CNT weight ratios 


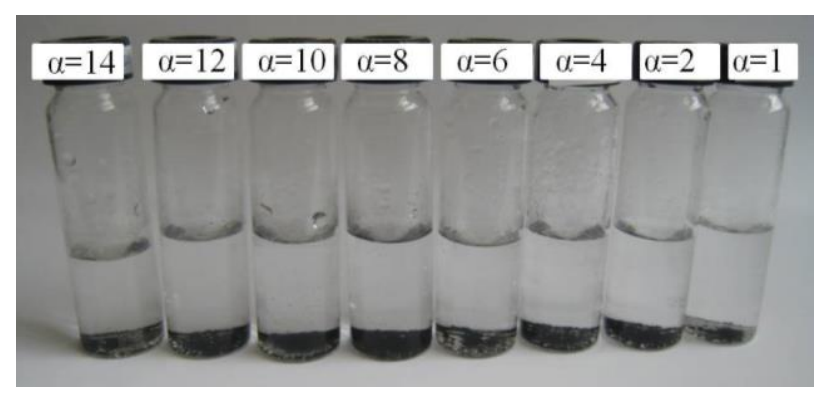

Figure 2. Evolution of the color of the suspensions in toluene of hybrid nanofillers with different MMT-to-CNT weight ratios

The dispersion was further measured by analyzing the suspensions using UV-visible spectrometry. The discovery of nanotube fluorescence [17] offers a precise method for detecting dispersion of individual nanotubes. Individual CNTs are active in the UV-vis region and exhibit characteristic bands corresponding to additional absorption due to 1D Van Hove singularities [18-20]. Bundled CNTs, however, are hardly active in the wavelength region between 200 and $1200 \mathrm{~nm}$ because their photoluminescence is quenched [21]. Therefore, it is possible to establish a relationship between the amount of CNTs individually dispersed in solution and the intensity of the corresponding absorption spectrum [22]. Experimentally, the comparison of dispersing ability by the UV-vis absorbance is plausible since the absorbance actually correlates well with the hybrid nanofiller concentration by following the Lambert-Beer law [23, 24]. The standard curves of absorbance against concentration were established at $550 \mathrm{~nm}$ for the hybrid nanofillers using the three different solvents: water (Figure 3), toluene (Figure 4 ) and carbon tetrachloride (Figure 5).

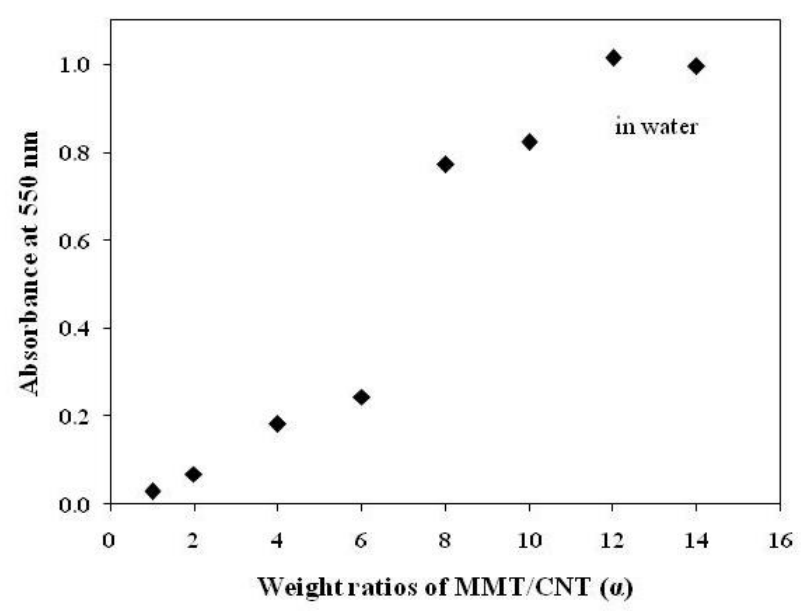

Figure 3. UV-vis absorbance of MMT/CNT hybrids at different $\alpha$ values in water

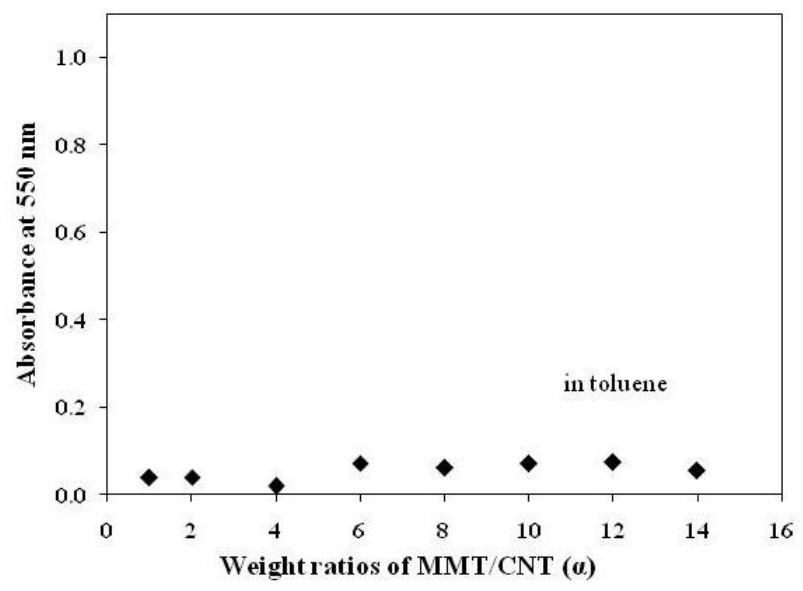

Figure 4. UV-vis absorbance of MMT/CNT hybrids at different $\alpha$ values in toluene

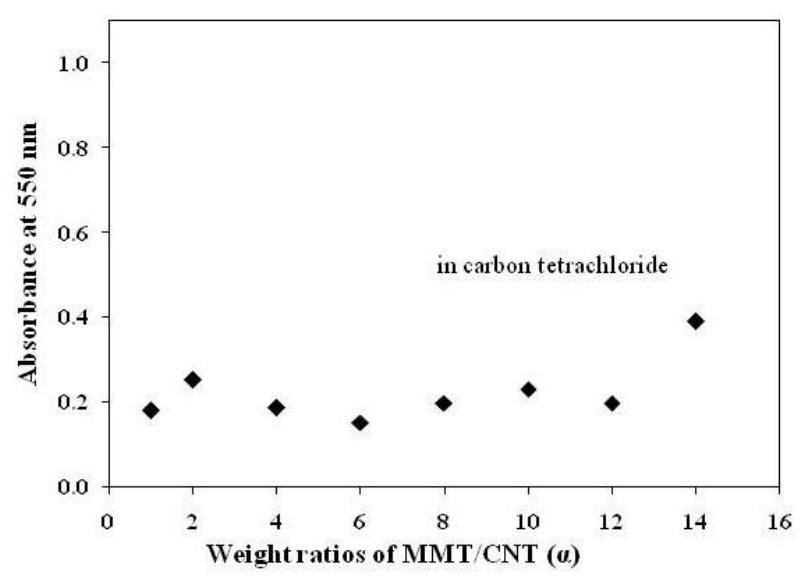

Figure 5. UV-vis absorbance of MMT/CNT hybrids at different $\alpha$ values in carbon tetrachloride

According to the UV-vis analyses MMT is most effective for enhancing the CNTs dispersion in water. The absorbance reached maximum when the MMT-to-CNT weight ratio $\alpha$ was 12 . For the toluene and carbon tetrachloride these maximums were significantly lower and were achieved, for toluene when $\alpha$ approached 6 and for carbon tetrachloride when $\alpha=14$. MMT is strongly hydrophilic and swollen in water but lacks dispersing ability in most organic medium. It appears that the presence of MMT actually affects the CNTs selfentanglement through interaction with the involved medium. When this interaction is strong, like in the case of the water, then the improvement of the CNTs dispersion is much higher.

Raman spectroscopy was utilized to evaluate the interactions between CNTs and MMT particles in the hybrid nanofillers. Figure 6 shows the Raman spectra for the CNTs and the hybrid nanofillers with $\alpha$ values of 1 and 6 . Raman spectra curves for 
the higher $\alpha$ values could not be recognized due to the strong scattering of the clay. CNTs have two characteristic peaks which are shown in Figure 6. These bands are the $\mathrm{G}$ band at $1584 \mathrm{~cm}^{-1}$ which is characteristic for the $\mathrm{C}-\mathrm{C}$ vibration of delocalized $p$-electrons with $\mathrm{sp}^{2}$ hybridization and the $\mathrm{D}$ band at $1340 \mathrm{~cm}^{-1}$ which is characteristic for defects in the graphitic structures with $\mathrm{sp}^{3}$ hybridization [25]. It is interesting to note that the addition of MMT in the hybrid nanofiller causes a considerable shift in both the $\mathrm{D}$ and $\mathrm{G}$ band by $20 \mathrm{~cm}^{-1}$ and $12 \mathrm{~cm}^{-1}$, respectively.

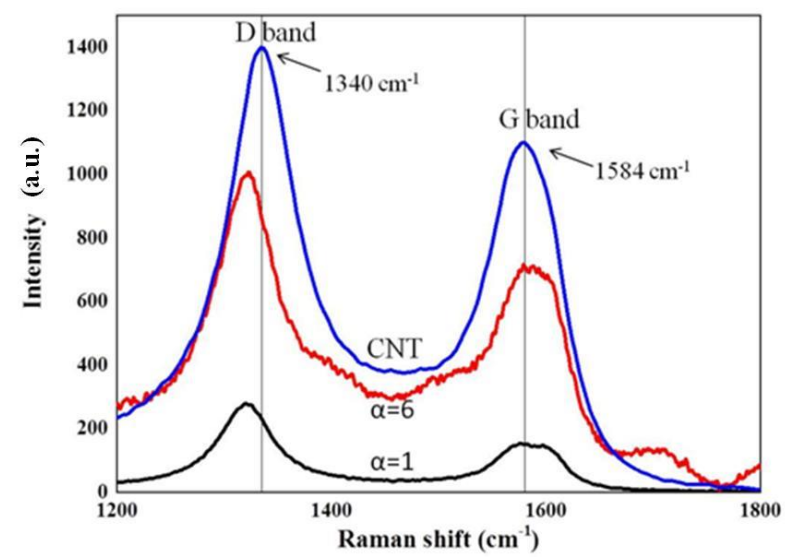

Figure 6. Raman spectra of CNTs and the hybrid nanofiller for $\alpha=1$ and 6

This shift of the $G$ band in the presence of MMT is an indication of physical interaction between CNTs and MMT particles which further improves the dispersion of the CNTs in the solvents. From Figure 6, the ratios of the peak intensity between $\mathrm{D}$ and $\mathrm{G}$ bands, $\mathrm{I}_{\mathrm{D}} / \mathrm{I}_{\mathrm{G}}$, were calculated. These ratios of the pristine CNTs, and CNT/MMT hybrids with $\alpha=1$ and $\alpha=6$ are $1.81,1.4,1.3$, respectively. The decrease of the $\mathrm{I}_{\mathrm{D}} / \mathrm{I}_{\mathrm{G}}$ ratios from the pristine CNTs to the hybrid nanofillers with different $\alpha$ values shows a decrease in disorder.
The results of TGA analysis, represented on Figure 7 , showed that the thermal stability of the hybrid nanofillers, as expected, increased with the increase of the MMT content. The increase of the clay content in the hybrid nanofiller resulted in increment in the decomposition temperatures (Table 1) compared with pure CNTs starting from temperatures at which $10 \%$ of mass loss occurred.

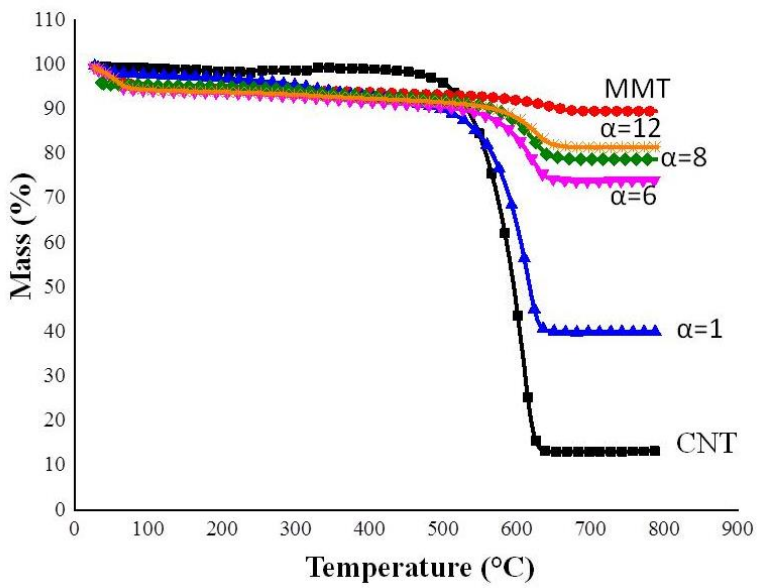

(a)

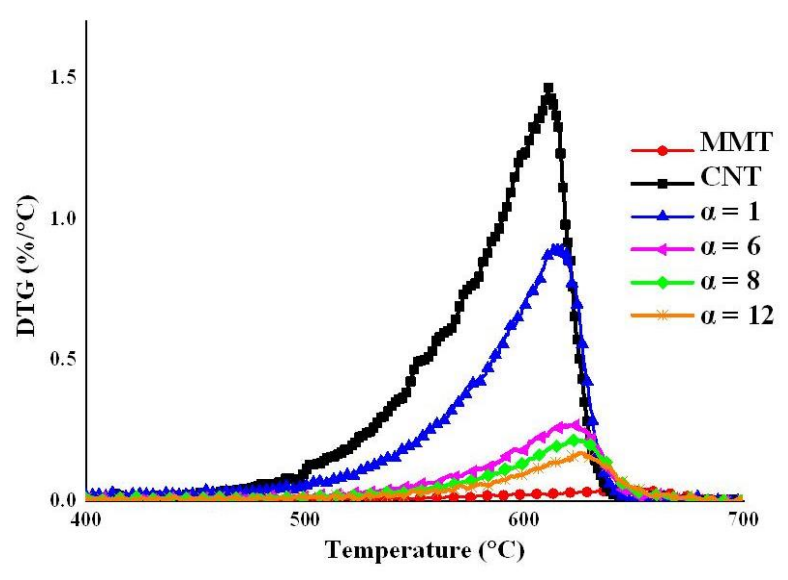

(b)

Figure 7. TGA thermograms (a) and DTG curves (b) of CNTs, MMT and their hybrids at different $\alpha$ values

Table 1. Temperatures of different mass losses and onset temperature of degradation for the pure CNTs, MMT and their hybrid nanofilers

\begin{tabular}{lcccccc}
\hline Sample & CNTs & MMT & $\boldsymbol{\alpha}=\mathbf{1}$ & $\boldsymbol{\alpha}=\mathbf{6}$ & $\boldsymbol{\alpha}=\mathbf{8}$ & $\boldsymbol{\alpha}=\mathbf{1 2}$ \\
\hline $\boldsymbol{T}_{\boldsymbol{d}}(\mathbf{- 1 \% )}$ & 137.2 & $/$ & 40.4 & 30.0 & $/$ & 30.9 \\
$\boldsymbol{T}_{\boldsymbol{d}}(\mathbf{- 2} \%)$ & 464.7 & 44.0 & 75.5 & 39.5 & $/$ & 43.1 \\
$\boldsymbol{T}_{\boldsymbol{d}}(\mathbf{- 5} \%)$ & 507.5 & 93.0 & 314.8 & 63.2 & 225.9 & 69.5 \\
$\boldsymbol{T}_{\boldsymbol{d}}(\mathbf{- 1 0} \%)$ & 532.9 & 663.0 & 496.8 & 523.3 & 568.8 & 570.4 \\
$\boldsymbol{T}_{\boldsymbol{d}}(\mathbf{- 1 5} \%)$ & 547.7 & $/$ & 545.5 & 591.9 & 612.9 & 624.0 \\
$\boldsymbol{T}_{\boldsymbol{d}}(-\mathbf{2 0} \%)$ & 557.9 & $/$ & 566.4 & 616.0 & 639.8 & $/$ \\
$\boldsymbol{T}_{\boldsymbol{d}}(-\mathbf{5 0} \%)$ & 595.8 & $/$ & 617.4 & $/$ & $/$ & $/$ \\
$\boldsymbol{T}_{\boldsymbol{d}}(-\mathbf{7 0} \%)$ & 611.3 & $/$ & $/$ & $/$ & $/$ & $/$ \\
$\boldsymbol{T}_{\text {onset }}$ & 522.9 & 560.2 & 537.2 & 557.4 & 560.8 & 563.3 \\
\hline
\end{tabular}


Table 2. Maximal rate of thermal decomposition determined from DTG-curves

\begin{tabular}{lcccccc}
\hline Sample & CNTs & MMT & $\boldsymbol{\alpha}=\mathbf{1}$ & $\boldsymbol{\alpha}=\mathbf{6}$ & $\boldsymbol{\alpha}=\mathbf{8}$ & $\boldsymbol{\alpha}=\mathbf{1 2}$ \\
\hline$T_{\max } /{ }^{\circ} \mathrm{C}$ & 610.9 & 656.5 & 616.5 & 619.9 & 624.7 & 624.6 \\
$V_{\max } / \%{ }^{\circ} \mathrm{C}^{-1}$ & $(69 \%)^{*}$ & $(10 \%)$ & $(49 \%)$ & $(21 \%)$ & $(17 \%)$ & $(15 \%)$ \\
\hline
\end{tabular}

* Weight loss at $T_{\max }$

For lower temperatures, the loss of mass was due to the evaporation of moisture that was captured in the clay galleries because MMT is strongly hydrophilic.

The improved thermal stability of the hybrid nanofillers compared to pure CNTs is also expressed through higher temperatures for the onset of thermal degradation (Table 1) and higher temperatures of maximum weight loss rate, determined from DTG curves presented in Figure 7 (b) (Table 2).

\section{CONCLUSIONS}

Hybrid nano fillers were produced by simply grinding CNTs with MMT into fine powder. The presence of MMT significantly enhanced the dispersion of CNTs in water, but not so much in toluene and carbon tetrachloride. This is due to the strong interaction between water as a medium and MMT and poor interaction with toluene and carbon tetrachloride. A proper modification of MMT could lead to a better dispersion of CNTs in the desired solvent. The shift of the $G$ band, in the Raman spectra, in the presence of MMT was an indication of a physical interaction between CNTs and MMT particles which further improves the dispersion of the CNTs in the solvents. The decrease of the $\mathrm{I}_{\mathrm{D}} / \mathrm{I}_{\mathrm{G}}$ ratios from the pristine CNTs to the hybrid nanofillers with different $\alpha$ values showed a decrease in disorder. TGA analysis showed that the thermal stability of the hybrid nanofillers increased with the increase of the MMT content compared to pure CNTs. This was expressed through higher temperatures for the onset of thermal degradation and higher temperatures of maximum weight loss rate.

The obtained results are a good contribution in identifying an easy, efficient, economical, ecological and industrially viable way of producing easily dispersible, super reinforcing hybrid nanofillers. The incorporation of such hybrid fillers in NR based matrixes and their influence on the composite properties will be investigated in our future work.

Acknowledgements. The authors thank Prof. Petre Makreski (Institute of Chemistry, Faculty for Natural Sciences and Mathematics - Skopje) for Raman spectroscopy measurements.

\section{REFERENCES}

[1] S. Iijima, Helical micro-tubules of graphitic carbon, Nature, 345 (1991), pp. 56-58.

[2] H. Dai, Carbon nanotubes: opportunities and challenges, Surf. Sci., 500 (2002), pp. 218-241.

[3] A. Thess, R. Lee, P. Nikolaev, H. Dai, P. Petit, J. Robert, C. Xu, Y. H. Lee, S. G. Kim, A. G. Rinzler, D. T. Colbert, G. E. Scuseria, D. Tomanek, J. E. Fischer, R. E. Smalley, Crystalline Ropes of Metallic Carbon Nanotubes, Science, 273 (1996), pp. 483-488.

[4] J. Chen, M. A. Hamon, H. Hu, Y. Chen,A. M. Rao, P. C. Eklund, R. C. Haddon, Solution Properties of Single-Walled Carbon Nanotubes, Science, 282 (1998), pp. 95-98.

[5] R. Yu, L. Chen, Q. Liu, J. Lin, K. L. Tan, S. C. Ng, H. S. O. Chan, G. Q. Xu, T. S. A. Hor, Platinum Deposition on Carbon Nanotubes via Chemical Modification, Chem. Mater., 10 (1998), pp. 718-722.

[6] M. L. Sham, J. K. Kim, Surface functionalities of multi-wall carbon nanotubes after UV/Ozone and TETA treatments, Carbon, 44(4) (2006), pp. 768777.

[7] S. C. Wang, K.S. Chang, C. J. Yuan, Enhancement of electrochemical properties of screen-printed carbon electrodes by oxygen plasma treatment, Electrochim. Acta, 54(21) (2009), pp. 4937-4943.

[8] L. Vaisman, H. D. Wagner, G. Marom, The role of surfactants in dispersion of carbon nanotubes, $A d v$. Colloid Interface Sci., 128 (2006), pp. 37-46.

[9] C. Y. Li, L. Li, W. Cai, S. L. Kodjie, K. K. Tenneti, Nanohybrid Shish-Kebabs: Periodically Functionalized Carbon Nanotubes, Adv. Mater., 17 (2005), pp. 1198-1202.

[10] V. Nicolosi, H. Cathcart, A. R. Dalton, D. Aherne, G. R. Dieckmann, J. N. Coleman, Spontaneous exfoliation of single-walled carbon nanotubes dispersed using a designed amphiphilic peptide, Biomacromolecules, 9 (2008), pp. 598-602.

[11] Y. F. Lan, J. J. Lin, Clay-assisted dispersion of organic pigments in water, Days Pigm., 90 (2011), pp. 21-27.

[12] Y. H. Pai, Clay as a dispersion agent in anode catalyst layer for PEMFC, J. Power Sources, 163 (2006), pp. 398-402. 
[13] Y. F. Lan, J. J. Lin, Observation of Carbon Nanotube and Clay Micellelike Microstructures with Dual Dispersion Property, J. Phys. Chem. A., 113 (2009), pp. 8654-8659.

[14] L. Liu, J. C. Grunlan, Clay assisted dispersion of carbon nanotubes in conductive epoxy nanocomposites, Adv. Funct. Mater., 17 (2007), pp. 23432348.

[15] Z. Wang, X. Meng, J. Li, X. Du, S. Li, Z. Jiang, T. Tang, A Simple Method for Preparing Carbon Nanotubes/Clay Hybrids in Water, J. Phys. Chem. C., 113 (2009), pp. 8058-8064.

[16] A. Ivanoska-Dacikj, G. Bogoeva-Gaceva, A. Buzarovska, I. Gjorgjiev, Lj. Raka, Preparation and properties of natural rubber/organomontmorillonite: from lab samples to bulk material, Maced. J. Chem. Chem. Eng., 33 (2) (2014), pp. 249-265.

[17] M. J. O’Connell, S. M. Bachilo, C. B. Huffman, V. C. Moore, M. S. Strano, E. H. Haroz, K. L. Rialon, P. J. Poul, W. H. Noon, C. Kittrell, J. Ma, R. H. Hauge, R. B. Weisman, R. E. Smalley, Band gap fluorescence from individual single-walled carbon nanotubes, Science, 297 (2002), pp. 593-596.

[18] H. Kataura, Y. Kumazawa,Y. Maniwa, I. Umezu, S. Suzuki, Y. Ohtsuka, Optical properties of single-wall carbon nanotubes, Synth. Met. 103 (1999), pp. 2555-2558.

[19] N. Hamada, S. Sawada, A. Oshiyama, New onedimensional conductors: graphitic microtubules, Phys. Rev. Lett., 68 (1992), pp. 1579-1581.

[20] R. Saito, M. Fujita, G. Dresselhaus, M. S. Dresselhaus, Electronic structure of chiral graphene tubules, App. Phys. Lett., 60 (1992), pp. 2204-2206.

[21] J. S. Laurent, C. Voisin, G. Cassabois, C. Delalande, P. Roussignol, O. Jost, Ultrafast carrier dynamics in Single-Wall Carbon Nanotubes, Phys. Rev. Lett., 90 (2003), pp. 057404.

[22] L. Q. Jiang, L. Gao, J. Sun, Production of aqueous colloidal dispersions of carbon nanotubes, J. Colloid Interface Sci., 260 (2003), pp. 89-94.

[23] Y. Qin, L. Liu, J. Shi, W. Wu, J. Zhang, Z. Guo, Y. Li, D. Zhu, Large-Scale Preparation of Solubilized Carbon Nanotubes, Chem. Mater., 15 (2003), pp. 3256-3260.

[24] D. Baskaran, J. W. Mays , M. S. Bratcher, Noncovalent and Nonspecific Molecular Interactions of Polymers with Multiwalled Carbon Nanotubes, Chem. Mater., 17 (2005), pp. 3389-3397.

[25] M. S. Dresselhaus, G. Dresselhaus, Light scattering in graphite intercalation compounds, App. Phys., 51 (1982), pp. 3-57.

\section{ПОДОБРЕНА ДИСПЕРЗИЈА НА ЈАГЛЕРОДНИТЕ НАНОЦЕВЧИЫА ВО РАЗЛИЧНИ РАСТВОРУВАЧИ СО ПОМОШ НА ГЛИНА}

\section{Александра Иваноска-Дациќ ${ }^{1}$, Гордана Богоева-Гацева ${ }^{1,2}$, Александра Бужаровска $^{2}$}

${ }^{1}$ Истражувачки центар за животна средина и материјали, Македонска академија на науките и уметностите, Скопје, Република Македонија

${ }^{2}$ Технолошко-металуршки факултет, Универзитет „Св. Кирил и Методиј“, Скопје, Република Македонија

Хибридни нанополнила составени од јаглеродни наноцевчиња (CNT) и монтморилонит (MMT) во различен сооднос беа подготвени со нивно физичко мешање. Беше испитано нивното дисперзионо однесување во различни растворувачи: вода, толуен и јаглентетрахлорид. UV-vis-спектрите на хибридните нанополнила во вода покажаа дека апсорпцијата на $550 \mathrm{~nm}$ станува поинтезивна со зголемување на содржината на ММТ, што укажува на подобрена дисперзија. Ова не е толку евидентно за растворите во толуен и јаглентетрахлорид. Термогравиметриската (TGA) анализа покажа зголемување на термичката стабилност на хибридните нанополнила со зголемување на количеството на ММТ. Со Рамановата спектроскопија се потврди интеракцијата меѓу CNT и MMT, демонстрирана преку поместување на лентите D и G карактеристични за Рамановиот спектар на CNT.

Клучни зборови: хибридно нанополнило; јаглеродни наноцевчиња; монтморилонит, дисперзивност 